\title{
MORTALITY OF WHITE SPRUCE IN THE LAKE NIPIGON REGION OF ONTARIO ${ }^{1}$
}

\author{
By J. B. THOMAS 2
}

\section{INTRODUCTION}

Preliminary findings of an investigation of the factors causing mortality of white spruce, Picea glauca (Moench) Voss, in the Lake Nipigon region of Ontario, first reported in 1951 by Belyea and Prebble (1), have been presented by Thomas $(8,9)$. Most of the spruce trees in the area had been severely defoliated by the spruce budworm, Choristoneura fumiferana (Clem.), for several years, and many had been killed. Survivors appeared to refoliate satisfactorily in the years immediately following the decline of the budworm outbreak in 1948, but dying white spruce became noticeable again by 1951 . Dead and dying trees examined from 1951 to 1955 had been attacked by bark beetles, chiefly Dendroctonus piceaperda Hopk., and Ips perturbatus Eichh., and these beetles appeared to be the immediate cause of death. Both species normally are present in the forests in endemic numbers, only reaching epidemic levels when an abundance of breeding material is available.

Reports of damage to spruce and balsam fir in the northeastern United States and in eastern Canada during the nineteenth century indicate a possible inter-relationship of outbreaks of the spruce budworm and bark beetles in the past. The death of spruce and balsam fir in this region was investigated by Packard (5) about 1880 to 1883 , his report appearing in 1890. A few years later, Hopkins (4) made a special investigation of the death of spruce in Maine, reporting his findings in 1901. Both these men felt that the mortality along the coastal areas was caused by the spruce budworm whereas damage to spruce in the interior resulted from bark-beetle attacks. Hopkins identified Dendroctonus piceaperda as the most important bark-beetle species. Much of the history of previous insect outbreaks written into their reports was pieced together from recollections of the inhabitants of the region resulting in some doubt as to just what insects were responsible for the damage in certain areas. Swaine and Craighead (7), having studied the accounts of past injury to spruce and balsam fir in the eastern United States and in eastern Canada, concluded that two general spruce budworm outbreaks had occurred before the one they were investigating began about 1909-1912. The first of these was widespread over the New England states and eastern Canada from 1800-1815; the second, also widespread, occurred between 1870 and 1880. Swaine and Craighead believed that, while the numerous reports of Packard and Hopkins concerning insect damage to spruce and balsam fir referred mostly to bark beetles, they could apply, at least in some cases, equally well to outbreaks of the spruce budworm. They thought that the spruce budworm outbreak about 1870, that Packard and Hopkins reported only along the coastal areas of Maine,

\footnotetext{
${ }^{1}$ Contribution No. 474, Forest Biology Division, Science Service, Department of Agriculture, Ottawa, Canada. Received for publication, May 16, 1958.

${ }^{8}$ Forest Insect Laboratory, Sault Ste. Marie, Ontario.
} 
was, in fact, much more extensive, and could have covered much of the territory where the damage was attributed to bark beetles. Again, the possible association of $D$. piceaperda with the spruce budworm is indicated by reports of the Dominion Entomologist, Dr. Fletcher, quoted in Swaine and Craighead (7). In his 1885 report, Dr. Fletcher noted injury to spruce in Quebec and New Brunswick and, while the spruce budworm was mentioned, most of the damage was attributed to bark beetles. In his next annual report published in 1887 , Dr. Fletcher had decided that the damage in Quebec was caused by D. piceaperda, and the spruce budworm was not mentioned.

While not all outbreaks of $D$. piceaperda are associated with outbreaks of the spruce budworm, it does appear that populations of this beetle have increased to epidemic numbers in association with the spruce budworm on more than one occasion in the past in eastern Canada and the United States.

\section{Bark BeEtles Breeding In Dying Spruce}

Dendroctonus piceaperda and Ips perturbatus were the most important species of bark beetles found in spruce in the Lake Nipigon area. In addition, Ips pini (Say), 1. borealis Sw., Polygraphus rufipennis (Kby.), Crypturgus atomus Lec., Dryocoetes affaber (Mann.), D. americanus Hopk., Pityophthorus consimilis Lec., $P$. nudus Sw., $P$. pulchellus Eichh., and Trypodendron lineatum (Oliv.) found trees attacked by the two major species suitable as breeding sites.

Early outbreaks of $D$. piceaperda in Maine and New Brunswick were investigated by Hopkins (4), and Swaine (6) discussed possible control measures for this beetle in eastern Canada. Watson (10) added to the known biology of this species by his studies of outbreaks in Ontario and later (unpublished reports) in the Gaspe Peninsula of Quebec. The biology of the second important species, 1 . perturbatus, was studied by Gobeil (3), in the Gaspe Peninsula. The seasonal development of both species in the Lake Nipigon region was studied, but since no differences from published accounts were discovered that could not reasonably be attributed to regional climatic conditions, details have not been included in this paper.

I. perturbatus is generally regarded as an important secondary species since it enters the trees after $D$. piceaperda. In the Lake Nipigon region, trees that were attacked by $D$. piceaperda usually were attacked later by $I$. perturbatus, but there were indications that, in certain case, I. perturbatus was of primary rather than secondary importance. Belyea and Prebble (1) reported that, in at least some of the trees dying in 1951, 1. perturbatus broods were completely developed in the upper trunk at mid-July while eggs had just been deposited in the lower part of the trunk by $D$. piceaperda. A similar condition was found in a few trees in 1953 and 1954.

\section{Recognition of Beetle-Atracked Trees}

The presence of pitch tubes formed of resin and boring dust about the entrance holes usually facilitates the detection of white spruce trees attacked by $D$. piceaperda. Where there is only a light flow of resin or none at all, however, the trees must be examined more closely for entrance holes and boring dust. Since pitch tubes do not normally form about the entrance holes of $\boldsymbol{I}$. 
perturbatus, attacks by this beetle can only be detected by location of the entrance holes or of the boring dust on the bark.

Changes in the color of the foliage not only provide the one means of detecting beetle-attacked trees from the air, but also the quickest way of locating these trees from the ground. Observations made in the Lake Nipigon region indicate, however, that the changes are not always consistent. In 1951, the foliage on many attacked trees had turned red by mid-July, but this con-

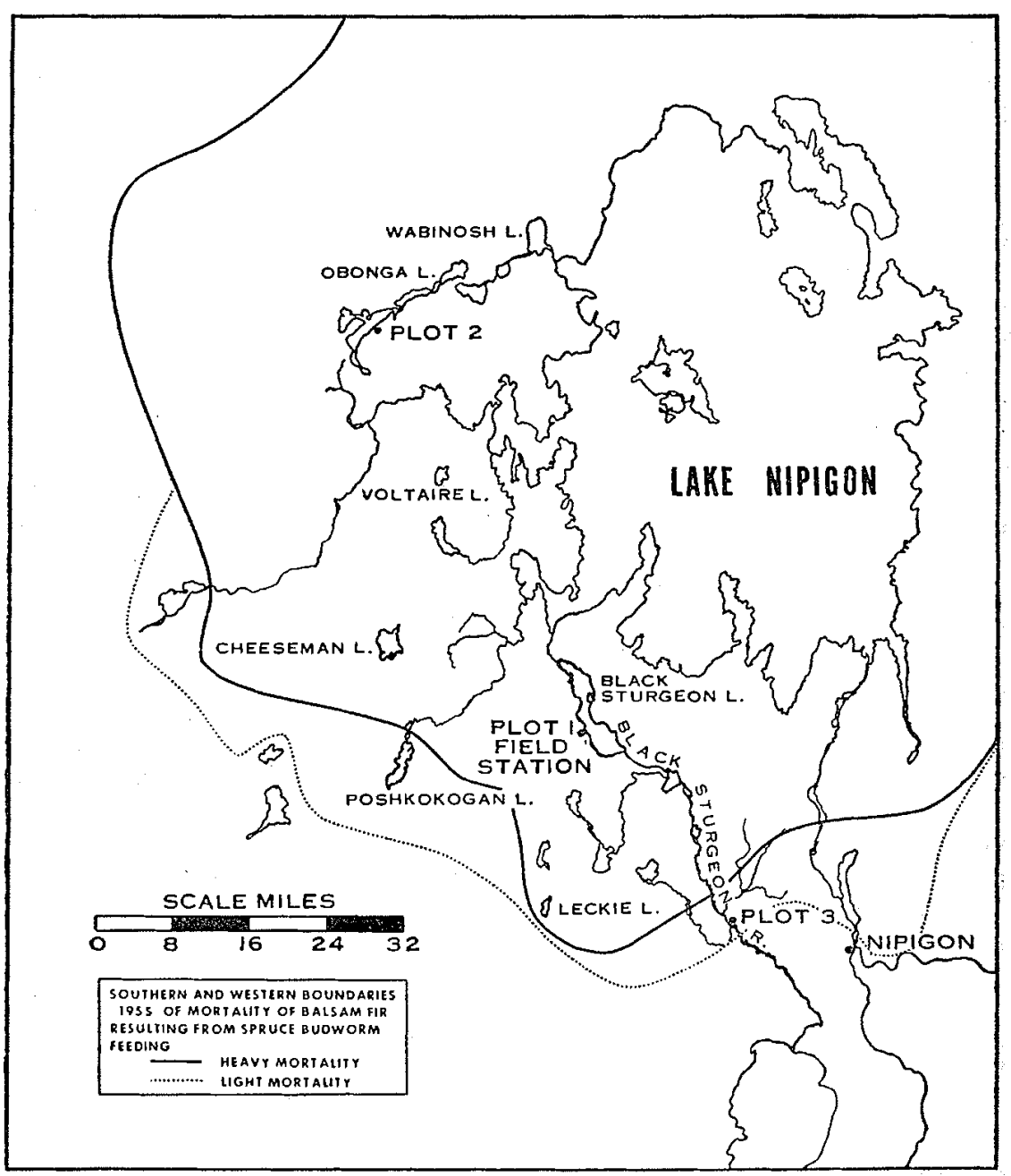

FIGURE 1

Location of white spruce mortality plots in the Lake Nipigon area. 
dition was rare in 1952 and 1953, becoming more prevalent again in 1954 . Periodic examinations in 1952 and 1953 of marked trees showed that the foliage of most trees attacked during the spring flight of beetles had turned a paler green by fall and had begun to drop from some trees. The remaining foliage turned greenish-yellow and fell by July of the succeeding year. The foliage of trees not attacked until summer showed very little color change until the spring and early summer of the next year when it turned greenishyellow and fell.

After the foliage drops, the bare twigs give the tree a rusty-brown tone. These observations suggest that, except where the foliage turns red, an infestation might not become apparent from the air until the foliage dropped the year after the the beetles attacked.

\section{Extent of Mortality in The L.ake Nipigon Region}

The 1955 southern and western boundaries of heavy and light mortality of balsam fir resulting from defoliation by the spruce budworm in the recent outbreak have been outlined in Fig. 1. These boundaries had remained essentially static since 1951 . By 1951 , considerable mortility of white spruce had already occurred within the area of heavy balsam-fir mortality, although surviving white spruce appeared to have refoliated satisfactorily. Aerial reconnaissance from 1951 to 1955 revealed that dying white spruce trees occurred singly or in small groups over the area of heavy balsam-fir mortality west and south of Lake Nipigon extending from Wabinosh and Obonga Lakes to Leckie Lake. In 1953, tree mortality appeared to be increasing in intensity in the southern regions around Cheeseman and Poshkokogan Lakes and particularly along the Black Sturgeon River. Defoliation of white spruce by the spruce budworm had been heavy in this area, but mortality was not as great as it had been closer to Lake Nipigon. The number of dying trees in the northern regions around Obonga Lake did not appear to increase noticeably from 1953 to 1955 , but small groups of recently-killed and dying white spruce were located east of Lake Nipigon in 1955. Tree mortality lessened in 1954 and newly-dead trees were not readily located in 1955 and 1956. These general impressions were confirmed by data from three study plots established within the area.

Plot 1, 7.5 acres in area, was established at Black Sturgeon Lake in September, 1952, in a stand composed of white spruce, jack pine, balsam fir, trembling aspen, white birch, and black spruce. There were 186 white spruce ranging from 6 to 23 inches in diameter included in the plot, trees below 6 inches D.B.H. not being tallied. Eight living trees, seven of which were over 16 inches in diameter, had been attacked by bark beetles in 1952; the beetles spread to five additional trees in 1953, but no attacks occurred within the plot after that year. As expected, all trees dead at establishment had been attacked by bark beetles, but only four had living $D$. piceaperda under the bark, indicating that these, at last, had been alive within the previous two years.

Plot 2, 0.4 acres in area, was also established in September, 1952, on the east shore of Obonga Lake, in a stand composed mostly of white and black spruce, balsam fir, and jack pine. The area surrounding the lake was in the centre of the recent spruce budworm outbreak, and heavy mortality of balsam 
fir and white spruce had occurred. Twenty-five white spruce trees, 9 to 24 inches in diameter, were tallied in this plot. Sixteen were dead when the plot was established and undoubtedly some of this mortality could be attributed to the spruce budworm alone as certain trees appeared to have been dead for several years. Nine of the dead trees had bark beetles still in them, however,

TABLE I

Distribution of D. piceaperda Attack on Living Spruce in Plot 3, 1953, ARranged as a $2 \times 14$ Contingency Table. (Expected Values on the Hypothesis of no Preference are Shown in Brackets beneath the OBSERVED FREQUENCIES)

\begin{tabular}{|c|c|c|c|}
\hline D.B.H. & Total & Attacked & $\begin{array}{l}\text { Difference } \\
\text { From } \\
\text { Expected }\end{array}$ \\
\hline 7 & 100 & $\begin{array}{c}1 \\
(13.18)\end{array}$ & -12.18 \\
\hline 8 & 71 & $\begin{array}{c}3 \\
(9.36)\end{array}$ & -6.36 \\
\hline 9 & 73 & $\begin{array}{c}6 \\
(9.63)\end{array}$ & -3.63 \\
\hline 10 & 44 & $\begin{array}{c}2 \\
(5.80)\end{array}$ & -3.80 \\
\hline 11 & 48 & $\begin{array}{c}5 \\
(6.33)\end{array}$ & -1.33 \\
\hline 12 & 51 & $\begin{array}{c}8 \\
(6.72)\end{array}$ & +1.28 \\
\hline 13 & 36 & $\begin{array}{c}3 \\
(4.75)\end{array}$ & -1.75 \\
\hline 14 & 30 & $\begin{array}{c}5 \\
(3.96)\end{array}$ & +1.04 \\
\hline 15 & 36 & $\begin{array}{l}12 \\
(4.75)\end{array}$ & +7.25 \\
\hline 16 & 25 & $\begin{array}{c}9 \\
(3.30)\end{array}$ & +5.70 \\
\hline 17 & 26 & $\begin{array}{c}8 \\
(3.43)\end{array}$ & +4.57 \\
\hline 18 & 23 & $\begin{array}{c}8 \\
(3.03)\end{array}$ & +4.97 \\
\hline 19 & 13 & $\begin{array}{c}5 \\
(1.71)\end{array}$ & +3.29 \\
\hline $20+$ & 8 & $\begin{array}{c}2 \\
(1.05)\end{array}$ & +0.95 \\
\hline & 584 & 77 & \\
\hline
\end{tabular}

Note: The figures in brackets indicate the ranking assigned to the real values to assist in comparison of the periods and classes. 
and six living trees had been attacked in 1952, indicating that recent bark beetle attack also had been quite severe. Three of the living trees attacked in 1952 were dead by late 1953, and the remainder appeared to have recovered. This plot was not checked after 1953 because of the few living trees left in it and its comparative inaccessibility.

Eight hundred and fffteen white spruce trees, 7 to 25 inches in diameter, were tallied in Plot 3, 10.0 acres in area, in September, 1953. This plot was located on the east bank of the Black Sturgeon River in Hele Township in a stand of white spruce, trembling aspen, balsam poplar, black spruce, and balsam fir, in approximately that order of importance. A point of particular interest in this plot is that the white spruce were 70 to 80 years old, 35 to 40 years younger than the spruce in Plots 1 and 2, but were of the same range of diameter. Seventy-seven of the 584 living trees had been attacked by $D$. piceaperda, and 23 of the 231 dead trees still had living beetles under the bark when the plot was established. In 1954, a further sixteen living trees were attacked by $D$. piceaperda, and six primarily by $I$. perturbatus. Attack declined in 1955 , only six trees being newly-attacked by $D$. piceaperda and four by 1. perturbatus in that year.

The data on mortality of white spruce in Plots 1 and 3 suggested that the incidence of attack was correlated with diameter, the larger trees being favored by the beetles, and these data have been analyzed to see if this was correct. The distribution of the 584 living trees in Plot 3, the larger of the two plots, has been treated as a $2 \times 14$ contingency table, and differences between observed numbers of trees attacked and the expected numbers if there was no preference have been listed in Table I. It is apparent that there is a definite trend in the lower diameter classes towards fewer attacked trees than expected, and above 13 inches, towards more attacked trees than expected. Testing the data, a chi square value of 74.23 was obtained for the 13 degrees of freedom, for which a chi square value of 34.53 would have sufficed to give a $p=.001$ level of significance. Since, in this table, many of the cells carry small frequencies, the data were regrouped in two ways; first, into a $2 \times 9$ table by the classes $7-9,10-11,12-13,14,15,16,17,18,19+$, and second into a $2 \times 7$ table by the classes $7-9,9-10,11-12,13-14,15-16,17-18,19+$. Chi square values of 69.31 and 70.93 were obtained, where values of 26.12 and 22.46 would have given a $p=.001$ level of significance. The chi square values achieved in these tests are seen to be from two to three times that required for a $\mathrm{p}=.001$ level of significance no matter how the data are grouped. It is concluded, therefore, that the trend observed towards increased attack in the higher diameter classes may be considered reliable, and has not resulted from the relatively low number of observations in each of the diameter classifications. Analysis of the data for Plot 1 produced a similar convincing conclusion.

The distribution of all trees in each of these two plots was set up as a contingency table, but no trend was apparent in the distribution of dead trees by diameter classes. This in no way refutes the results of the tests with living trees, however, since factors other than bark-beetle attack contributed to the total mortality in each plot. 


\section{ANALYsIS OF GROWTH}

Annual increment of living and dead white spruce trees has been used as an indicator of tree vigor to assess the importance in causing tree mortality of feeding by the spruce budworm alone or in combination with later attacks by bark beetles. Faster-growing trees have been considered the more vigorous.

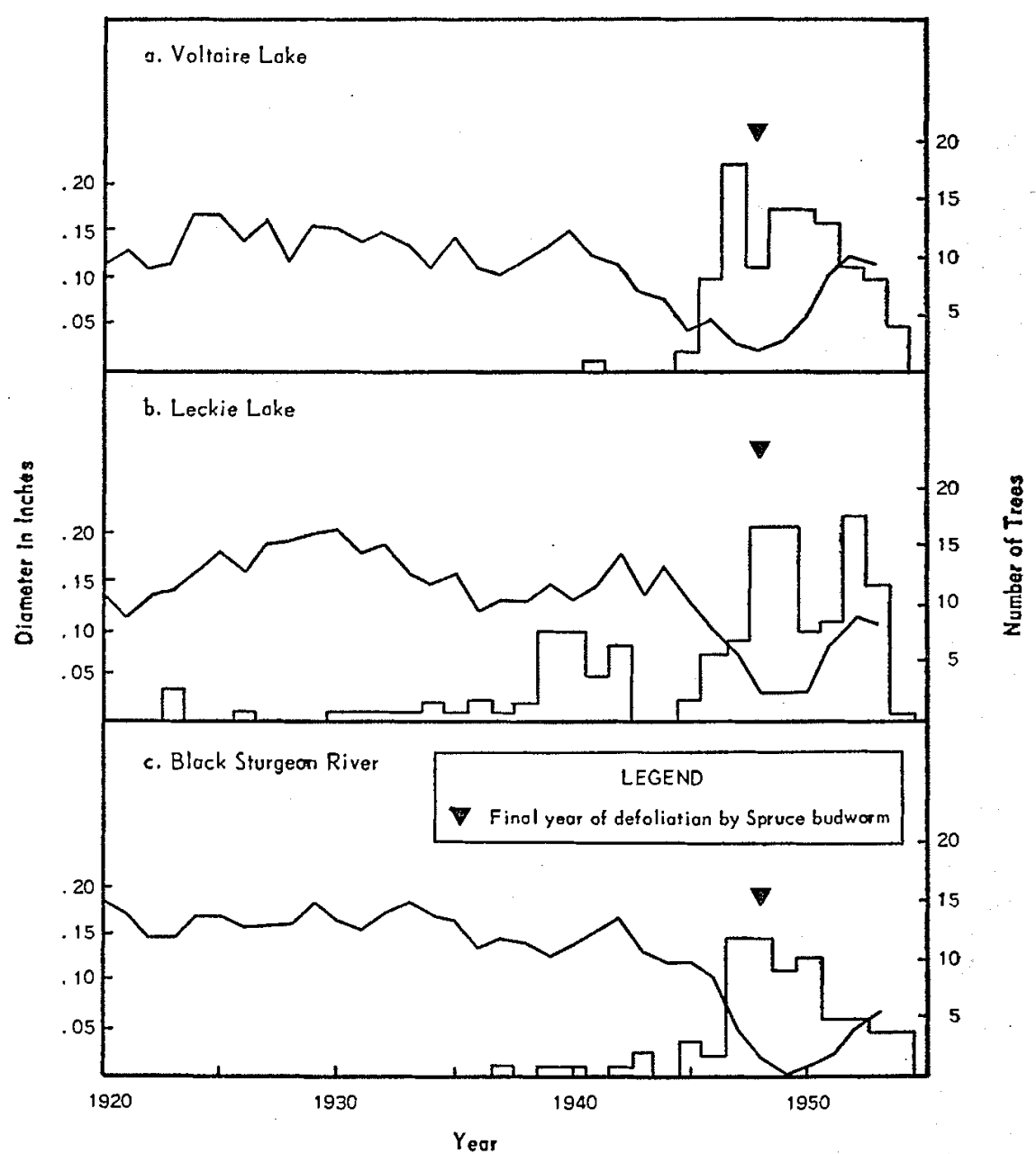

FIGURE 2

Numbers of dead white spruce trees plotted over a graph of average annual increment of living white spruce. The depression in annual increment centred about the years 1948-1949 was caused by defoliation by the spruce budworm. 
Annual increment was measured using a binocular microscope, and the values obtained from the average of the readings from three radii on a disc or wedge, or from two or more increment cores, have been used to compare growth rates of living and dead trees in various periods and from different areas. The last year of increment for dead trees was determined by the technique outlined by Ghent (2). Frequencies of dead trees have been plotted in Fig. 2 as histograms superimposed on frequency polygons of the average annual increment of living white spruce from Voltaire Lake, Leckie Lake, and the Black Sturgeon River (Plot 3). The sample from Leckie Lake included 144 dead white spruce on 12 acres of a permanent research area, whereas the samples at Voltaire Lake and the Black Sturgeon River, 100 and 72 trees respectively, represented only a portion of the dead trees present in the stand. Mortality in all areas could have been caused by windthrow, climatic conditions, deterioration of site, reduced tree vigor, feeding by the spruce budworm, attacks by bark beetles, or a combination of these factors, but it has been assumed that, in the period after decline in growth due to feeding by the spruce budworm, most of the trees died as a direct result of this feeding and/or later attacks by bark beetles. The numbers of trees used for comparative growth rate analysis (those dying after the period of growth decline due to budworm feeding) were 99, 101, and 68 at Voltaire Lake, Leckie Lake, and the Black Sturgeon River, respectively.

Naturally, it is impossible to say with any certainty what proportion of the trees were killed by defoliation by the spruce budworm alone, by attacks by bark beetles, or by a combination of these agents. The last year in which general defoliation by the spruce budworm occurred in the recent major outbreak was 1948. The data presented in Fig. 2, however, show that a considerable number of trees, amounting to 71.7 per cent of the net sample at Voltaire Lake, 64.4 per cent at Leckie Lake, and 54.4 per cent at Black Sturgeon River, died after 1948. Bark beetles were known to be active in white spruce in these areas from 1951 on, and it seems logical to assume that many of the trees would have survived had it not been for attacks by these beetles. Such an assumption is complicated by the recurrence of spruce budworm in two of the sample areas. At Leckie Lake budworm populations increased in 1952, and defoliation of the current year's foliage of balsam fir that had survived earlier destruction was over 80 per cent in 1953 and 1954. Defoliation of surviving white spruce was also heavy but was not measured. In 1955, defoliation dropped to 12 per cent of the current foliage on balsam fir and further to 2 per cent in 1956. At the Black Sturgeon River, defoliation of white spruce was less than 20 per cent in 1954, 23 per cent in 1955, and down to 17 per cent in 1956. The second period of defoliation might have contributed to the mortality near Leckie Lake, but it is unlikely that it had any effect at the Black Sturgeon River location, and one must conclude that bark beetles were the important insects. The data presented in Fig. 2 show that tree mortality did not stop with the termination of feeding by the spruce budworm, and it is suggested that the increase in numbers of bark beetles, particularly $D$. piceaperda and 1 . perturbatus, from an endemic level to the point where they can attack and kill trees independently of the budworm, may be 
TABLE II

Mean InCRements in INChes of Diameter for Designated Ten-Year Periods

\begin{tabular}{|c|c|c|c|c|c|}
\hline \multicolumn{6}{|l|}{ Leckie Lake } \\
\hline \multirow[t]{2}{*}{ Survival Classes } & \multirow[t]{2}{*}{$\mathbf{n}$} & \multicolumn{4}{|c|}{ Periods } \\
\hline & & I (1905-14) & II $(1915-24)$ & III (1925-34) & IV (1935-44) \\
\hline \multicolumn{6}{|c|}{ 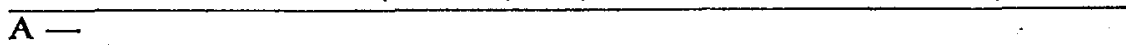 } \\
\hline $\begin{array}{l}\text { Died 1945-49 } \\
\mathrm{B}-\end{array}$ & 34 & 0.70 (4) & $0.63(4)$ & $0.63(4)$ & 0.67 (4) \\
\hline $\begin{array}{l}\text { Died 1950-51 } \\
\text { C - }\end{array}$ & 14 & $1.05(2)$ & $0.93(2)$ & $0.90(2)$ & 0.73 (3) \\
\hline $\begin{array}{l}\text { Died 1952+ } \\
\text { D - }\end{array}$ & 32 & 0.92 (3) & $0.86(3)$ & 0.88 (3) & $0.76(2)$ \\
\hline \multirow[t]{2}{*}{ Living } & 13 & 1.45 (1) & 1.49 (1) & $1.66(1)$ & 1.39 (1) \\
\hline & 93 & & & & \\
\hline
\end{tabular}

Black Sturgeon River

\begin{tabular}{|c|c|c|c|c|c|}
\hline \multirow[t]{2}{*}{ Survival Classes } & \multirow[t]{2}{*}{$\mathbf{n}$} & \multicolumn{4}{|c|}{ Periods } \\
\hline & & I (1905-14) & II (1915-24) & III (1925-34) & IV (1935-44) \\
\hline $\mathrm{A}-$ & & & & & \\
\hline $\begin{array}{l}\text { Died 1945-49 } \\
\mathrm{B}-\end{array}$ & 15 & 2.39 (3) & 1.57 (4) & 1.11 (4) & $0.76(4)$ \\
\hline $\begin{array}{l}\text { Died 1950-51 } \\
C-\end{array}$ & 9 & $2.30(4)$ & 1.59 (3) & 1.13 (3) & $0.80(3)$ \\
\hline $\begin{array}{l}\text { Died } 1952+ \\
D \text { - }\end{array}$ & 15 & 2.85 (1) & 1.90 (2) & 1.40 (2) & $0.92(2)$ \\
\hline Living & 18 & $2.62(2)$ & 2.16 (1) & 1.65 (1) & 1.23 (1) \\
\hline & 57 & & & & \\
\hline
\end{tabular}

Voltaire Lake

\begin{tabular}{|c|c|c|c|c|c|}
\hline \multirow[t]{2}{*}{ Survival Classes } & \multirow[t]{2}{*}{$\mathbf{n}$} & \multicolumn{4}{|c|}{ Periods } \\
\hline & & I (1901-10) & II $(1911-20)$ & III $(1921-30)$ & IV (1931-40 \\
\hline$A-$ & & & & & \\
\hline $\begin{array}{l}\text { Died 1941-48 } \\
\text { B - }\end{array}$ & 25 & $1.39(4)$ & $1.01 \quad(4)$ & 0.87 (4) & 0.93 (4) \\
\hline $\begin{array}{l}\text { Died 1949-50 } \\
C-\end{array}$ & 19 & 2.02 (1) & $1.30(2)$ & $1.25(2)$ & $1.15(2)$ \\
\hline $\begin{array}{l}\text { Died 1951+ } \\
\text { D - }\end{array}$ & 24 & 1.61 (3) & $1.14(3)$ & $1.16(3)$ & 1.13 (3) \\
\hline Living & 6 & $1.77(2)$ & $1.58(1)$ & 1.46 (1) & 1.32 (1) \\
\hline
\end{tabular}

Note: The figures in brackets indicate the ranking assigned to the real values to assist in comparison of the periods and classes. 
a natural development in a spruce-balsam fir forest subjected to a severe and prolonged outbreak of the spruce budworm.

To see if the time of death of the white spruce was related to growth rate, as one would expect, the annual increment of dead trees at the three locations was compared with that of living white spruce. The trees were placed in four survival classes: Class A included those trees that died while the budworm was most active; Class B, those that died immediately after the budworm outbreak, but before bark beetles became prevalent; Class C, those that died during this later period of heavy bark beetle attack; and Class D, those that were still living at the time of the study. At Voltaire Lake, Class A included trees dying during the period 1941-1948; Class B the period 1949-1950; and Class C the period 1951-1954. At Leckie Lake and the Black Sturgeon River, Class A included trees dying during the period 1945-1949; Class B the period 1950-1951; and Class $C$ the period 1952-54. While the actual years of death of trees in the sample at Voltaire Lake are not the same as those in the other areas, the periods relative to the history of the spruce budworm outbreak are believed to be the same.

Annual increment was analyzed over four ten-year periods preceding the beginning of decline in increment caused by feeding of the spruce budworm. It was felt that radial increment during and after the period of budworm feeding could not be readily analyzed since the death of so many trees during this period reduced the sample size considerably. As in the survival classes, there are two sets of calendar years for the four periods of increment, but these represent the same growth periods relative to the development of the spruce budworm outbreak in the different locations. Selection of the dead trees used in the analysis was restricted to those falling within the diameter range of the surviving living trees. The mean increments for the ten-year periods have been listed for each area by survival classes in Table II. To exhibit trends more readily, the growth values have been ranked numerically in each group, 1 being assigned to the largest value, and the rank position has been placed in brackets beside each real value.

Analysis of variance of the data indicated a significant difference in increment between survival classes within each of the three areas. As one would expect, the surviving trees had been faster-growing in nearly every case than any of the trees that died, and trees that died first after defoliation by the spruce budworm had put on the least increment for the previous forty years. Differences between Classes B and C were very small, and separation into these two groups probably was not justified.

Since an analysis of the distribution among diameter classes of trees attacked by $D$. piceaperda showed that this beetle tended to attack larger trees in preference to smaller ones, the possibility that trees of a certain vigor class were also preferred was examined. Although the mean increment of attacked trees was found to be less than that of unattacked trees in each of five tenyear periods from 1902 to 1951 , analysis of these data showed that the minor differences were not significant.

\section{Discussion}

As pointed out in the introduction to this paper, an appraisal of the reports 
and publications of Packard (5), Hopkins (4), and Swaine and Craighead (7), suggests that early outbreaks of the bark beetle, $D$. piceaperda, and of the spruce budworm in eastern Canada and the northeastern part of the United States may have been associated. Both Packard and Hopkins had to rely upon recollections of people living in the area to formulate their opinions of the past history of the agents responsible for the damage to spruce and balsam fir. This, along with the fact that the main destructive effect of the budworm probably was on balsam fir, a "weed" tree at that time, whereas much of the mortality of the valuable white spruce was attributed to $D$. piceaperda, possibly explains why outbreaks of these two insects were connected in so few instances. Results of this investigation, however, strengthen the evidence that an increase in the bark beetle population may be expected to follow a severe outbreak of the spruce budworm in areas supporting white spruce as well as balsam fir, with a consequent loss of many spruce trees that appear to have survived defoliation by the spruce budworm.

The increased supply of weakened and dying white spruce trees provided by the spruce budworm is believed to be the major factor permitting the bark beetle population to increase to destructive numbers from an endemic level. Other factors, however, tend to limit the outbreak period. The bark beetle attack in the Lake Nipigon region, in general, appeared to involve single trees or clumps of trees over the area of spruce budworm infestation, and the scattered distribution of white spruce prevented these localized spots of high population from coalescing and intensifying the outbreak. Also, it has been shown that in general the least vigorous trees died first when the spruce budworm was most prevalent, and the more vigorous trees died after defoliation ended and bark beetles were more prevalent. Trees that were living at the time of the study were the most vigorous. This forced the beetles, if they were to spread, to attack more vigorous trees as time went on, thereby reducing their chances of survival. While it has not been proven that the fecundity of D. piceaperda is less in small-diameter trees than in larger trees, the tendency for the beetles to attack larger trees in preference to smaller ones has been substantiated. It is believed, therefore, that this preference may act as a limiting factor in the spread of an outbreak as the number of trees of the preferred size is reduced. At the same time it is this characteristic of the behavior of the beetle that increases its destructive effect.

The interpretation placed on the records of former outbreaks of the spruce budworm and $D$. piceaperda, along with the results of this study of events in the Lake Nipigon region, indicates that outbreaks of this bark beetle may be a natural development in a spruce-balsam fir forest subjected to a severe outbreak of the spruce budworm. This should be taken into consideration in any plan formulated for the management of a forest of this type, and particularly in the presalvage and salvage of trees from areas being attacked by the spruce budworm.

\section{REFERENCES}

1. BELYEA, R. M. and M. L. PREBBLE, 1951. Mortality of white spruce, Lake Nipigon area. Can. Dept. of Agr., Div. For. Biol. Bi-Mon. Prog. Rept. $7(6)$.

2. GHENT, ARTHUR, W. 1952. A technique for determining the year of the outside ring of dead trees. For. Chron. $28(4)$. 
3. GOBEI, A. R. 1936. The biology of Ips perturbatus Eichhoff. Can. Jour. Res. D. 14.

4. HOPKINS, A. D. 1901. Insect enemies of the spruce in the northeast. U.S.D.A. Div. of Ent. Bull. 28 a.s.

5. PACKARD, A. S. 1890 . Insects injurious to forest and shade trees. Fifth Report of the U.S. Ent. Commission, U.S.D.A.

6. SWAINE, J. M. 1924. The control of the destructive spruce bark beetle in eastern Canada. Dom. of Can. Dept. of Agr. Pamphlet No. 48 n.s.

7. SWAINE, J. M. and F. C. CRAIGHEAD. 1924. Studies on the spruce budworm (Cacoecia fumijerane Clem.) Dom. Dept. of Agric. Bull. 37 n.s. (Technical).

8. THOMAS, J. B. 1953. Mortality of white spruce, Lake Nipigon area. Can. Dept. of Agriculture, Div. For. Biol. Bi-Mon. Prog. Rept. 9(2).

9. THOMAS, J. B. 1954. Mortality of white spruce, Lake Nipigon area. Can. Dept. of Agr., Dir. For. Biol. Bi-Mon. Prog. Rept. $10(6)$.

10. WTSON, E. B. 1928. The bionomics of the spruce bark beetle Dendroctonus piceaperda Hopt. Scientific Agr. 3(10). 